\title{
薬剤師による臨床判断と新しい臨床技能を育てるアドバンスト学部教育カリキュラム
}

\author{
木内祐二, * 増田 豊, 亀井大輔, 向後麻里, 中村明弘
}

\section{Advanced Curriculum for Clinical Assessment and Skill in New Age Pharmacist Education}

\author{
Yuji Kiuchi, ${ }^{*}$ Yutaka Masuda, Daisuke Kamei, Mari Kogo, and Akihiro Nakamura \\ School of Pharmacy, Showa University; 1-5-8 Hatanodai, Shinagawa-ku, Tokyo 142-8555, Japan.
}

(Received September 4, 2012)

\begin{abstract}
In Showa University School of pharmacy, 7 competencies for outcome-based education were set up in 2011. We are now creating sequential curriculum in order to achieve these competencies. As a member of team medical treatment, pharmacist must share a patient's information with other members, assess each patient's condition, propose the best medication with evidence, and also check the effect of medication. Therefore, many active practices in a hospital and community and problem-based learning (PBL) tutorials are carried out in curriculum in School of Pharmacy. As a training for the future pharmacists who positively perform primary care with responsibility in community pharmacy, students study the method of clinical assessment (assessment of condition of disease from the patient's complain, and choice of appropriate proposal). Furthermore, the exercise and training of parenteral medication, physical assessment, and first aid, etc. are also taken in the curriculums as new clinical skill. The systematic and gradual interprofessional education curriculum for the team medical education has been carried out aiming at training of active members in medical team in a hospital and community. At this symposium, I will introduce these systematic advanced curriculums for the pharmacist of a new age, and to show the usefulness and learning effect.
\end{abstract}

Key words — pharmacist education; competency; interprofessional education; clinical assessment; clinical skill; advanced curriculum

\section{1. 昭和大学の特色}

昭和大学は, 医学部, 歯学部, 薬学部, 保健医療 学部 (看護学科, 理学療法学科, 作業療法学科) か らなる医系総合大学 (1 学年約 600 人, 薬学部は約 200 名）であり，大学の教育理念に「学部の枠を越 えてともに学び，互いに理解し合え，協力できる人 材を育成する」ことを明記し，チーム医療に積極的 に貢献できる人材養成を全学部に共通する教育の目 的としている.

1 年次は山梨県の富士吉田キャンパスで 4 学部学 生が全寮制教育を受け，2 年次以降は東京都品川区 の旗の台キャンパスで医・歯・薬学部, 大学病院が 併置された環境で学習し, 各学部の学生, 教員の学 部間交流が日常的である。また，全国の医系大学で 最大の附属 8 病院（約 3200 床）で多彩な臨床実習

The authors declare no conflict of interest.

昭和大学薬学部（干142-8555 東京都品川区旗の台 1-58)

*e-mail: ykiuchi@pharm.showa-u.ac.jp

本総説は, 日本薬学会第 132 年会シンポジウム S07 で

発表をしたものを中心に記述したものである.
と各学部の学生受入れができるという特色を持つ. こうした学習環境を活かし，体系的なチ一ム医療教 育を始め, 薬剤師の多様な臨床能力の修得を目的と したアドバンスト学部教育カリキュラムを導入して いる.

2. 学習アウトカム (コンピテンシー) の作成 昭和大学薬学部では, カリキュラム改善を目的 に, 毎夏, 薬学部アドバンストワークショップを開 催している. 平成 23 年 8 月 17-19 日の第 6 回ワー クショップでは，学習成果基盤型教育 (Outcomebased Education）の導入を試み, 「昭和大学薬学部 学生が卒業時に有している能力」, すなわち学習ア ウトカム（コンピテンシー）を検討した. ${ }^{1}$ )コンピ テンシーの条件として，6 年制薬学部のアウトカ ム, 卒業時にすべての学生が到達し, 評価が可能な 能力, 昭和大学の特色を活かしたもの, 10 年後の 医療と薬剂師を想定したもの，知識・技能・態度が 統合された能力， 6 年間を通して体系的，段階的に 修得する能力, 社会にも学生にもわかり易い表記, として作成作業を行った。十分に時間をかけて討議 


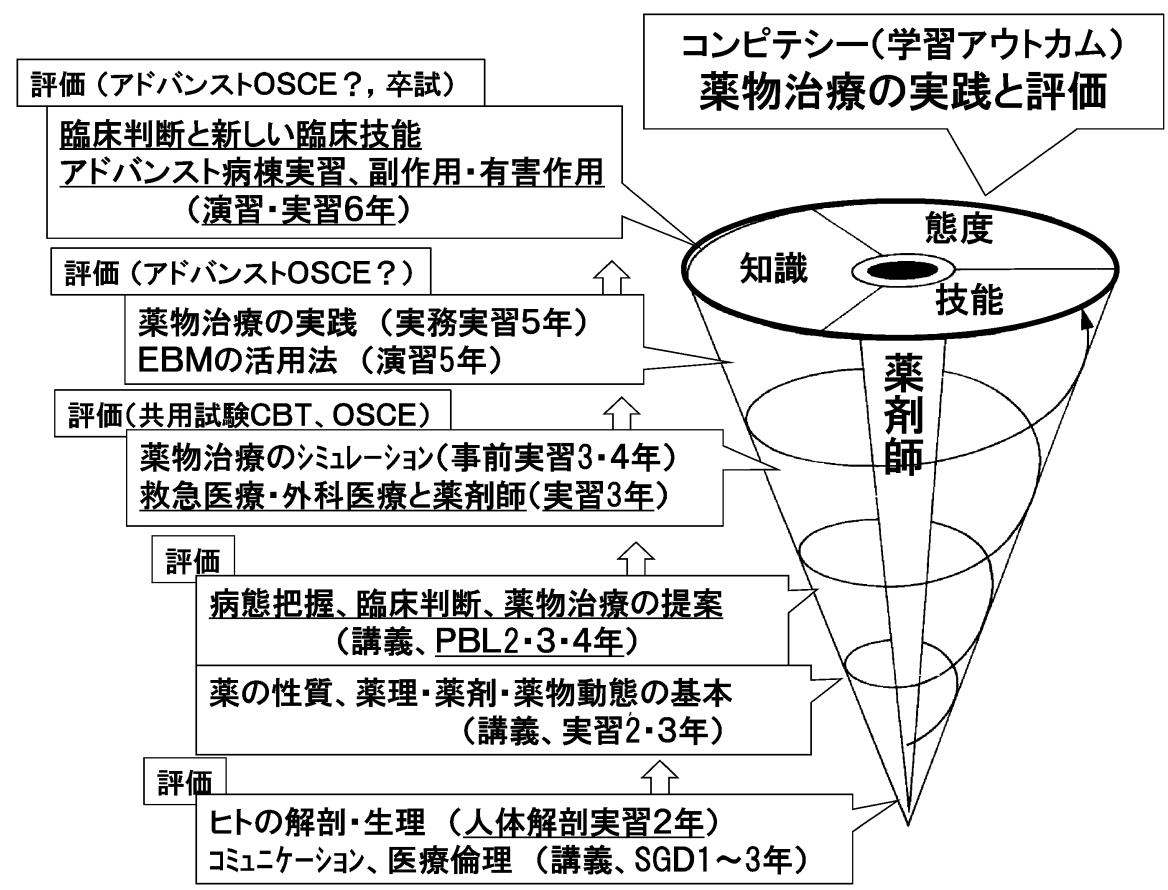

Fig. 1. Spiral Curriculum for a Competency "Practice and Evaluation of Medication" in Showa University School of Pharmacy

した結果，以下の 7 つを「昭和大学薬学部学生が卒 業時に有している能力 (コンピテンシー)」とし, 平成 24 年度のシラバスに明記し，学生にもその詳 細を説明した。

1. プロフェッショナリズム

2. コミュニケーション能力

3. 患者中心のチーム医療

4. 医薬品の調製，管理，供給

5. 薬物治療の実践と評価

6. 地域への貢献

7. 薬学研究と自己研鑽

各コンピテンシーには，到達レベルを示すための 簡単な説明文も付記した。卒業時にこれらのコンピ テンシーを修得するためには，基礎的な知識，技 能，態度の学習から，それらを組み合わせて応用し たシミュレーション学習, 医療現場での実践的な学 習まで，らせん型に繰り返して学習するカリキュラ ムを構築し，適切な時期に適切な評価を実施する必 要がある. 現在, 昭和大学薬学部の現行のカリキュ ラムが，コンピテンシーの修得のために望ましい内 容をらせん型に学習するものなっているかを再確認 し，コンピテンシーの到達度の適切な評価方法につ いても検討を加えている.

3.「薬物治療の実践と評価」の体系的カリキュ ラム

上記のコンピテンシーのうち,「薬物治療の実践 と評価」に関しては，到達レベルを示す説明文とし て以下を付記した。

- 患者の病態を把握して，科学的な根拠と医薬 品の特性に基づいて，適切な薬物治療を実践で きる.

・ 薬物治療の効果と副作用を適切に評価できる.

卒業時に「薬物治療の実践と評価」の上記の到達 レベルに至るために，昭和大学薬学部では，現行の 科目を基に, Fig. 1 のようならせん型カリキュラム を想定している，図中の下線のある科目は，医系総 合大学の昭和大学の特色を活かした科目であり，そ れらを中心に，体系的な「薬物治療の実践と評価」 について紹介したい。

3-1. 問題解決型学習 : PBL チュートリアルと統

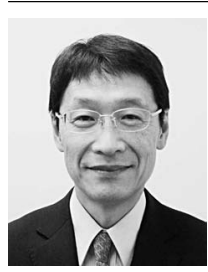

木内祐二
昭和 34 年東京生まれ，東京医科歯科大 学医学部, 昭和大学大学院修了後, 昭 和大学医学部薬理学で精神薬理をテー マに研究. 平成 10 年から昭和大学薬学 部病態生理学教授, 22 年から薬学教育 推進室教授。新たな薬学・薬剤師教育 及びチーム医療教育の卒前・卒後カリ キュラム作成と運営に取り組んでいる。 
合型学習 Problem-based learning (PBL) チュー トリアルは，6-10 人程度の学生にファシリテー ター 1 人が支援を行う小グループ学習であり，通常 は提示された臨床症例について全員で討議し問題解 決を行う。臨床上の問題抽出と臨床推論, 患者の問 題解決, 統合的学習・知識の総合, 自学自習, 能動 的学習，医療コミュニケーションなどの能力の修得 が期待される。「薬物治療の実践と評価」の問題解 決型学習に有用であり，チーム医療，患者中心の医 療のシミュレーションともなるため, ${ }^{2)}$ 昭和大学で は各学年に取り入れており，薬学部は 1 学年 200 名 の学生を 20-24 グループに分けて実施している (Table 1 (1)). 1，3，4 年次には，4学部連携型の PBL チュートリアルも実施している (後述).

また，高学年では，知識，技能，態度を統合した 問題解決型学習として，ファーマシューティカルケ ア実習を取り入れた「実務実習事前学習」，担当患 者を受け持つ「病院・薬局実習」のほか，患者シナ リオによる演習とロールプレイや実技実習などを組 み合わせた選択科目「総合薬学演習」（5 年）と 「臨床判断と薬剤師」（6 年）で，薬物治療に関する 実践的な学習を実施している（Table 1 (2)）.

3-2. 救急医療 · 外科医療の導入教育 従来の 薬学部教育では, 救急医療を始めとする急性期医療 や外科医療に関する学習が少なく，こうした領域で の薬物治療の理解や実践能力の修得が不十分であつ た。 そこで, 昭和大学では, 急性期医療, 救急・外 科医療の「薬物治療の実践と評価」導入教育として, 3 年次後期に選択科目（約 100 名）であるが，実質 11 日間にわたつて「救急医療・外科医療と薬郕師」 を実施している．医学部と大学の附属病院の協力を 得て, 事前学習 (救急と外科・麻酔医療を専門医の 講義・演習, SGD), 手術見学, 救急医療センター 見学, 救急蘇生実習 (AED+心肺蘇生, 超音波診 断，バイタルサイン測定）と発表会を組み合わせた 学習を行っている (Fig. 2).

3-3. 薬剤師の臨床判断と新しい臨床技能 10 年後の医療と新たな薬剤師職能を想定して, 6 年前 期の選択科目「薬剤師の臨床判断」（約 40 名）で, 今後, 薬剂師に求められる新たな臨床技能を用いた 臨床判断と治療の実践3,4) の学習を導入した。 5 週間 （全日）の学習期間で，プライマリケアのための臨 床判断 (前半), 急性期医療に参加するための臨床
Table 1. Systematic Problem-solving Learning for "Practice and Evaluation of Medication"'

「薬物治療の実践と評価」のための体系的な問題解決型学習

(1) PBL チュートリアル 1-4 年

$>1$ 年通年「チーム医療の基盤」

4 学部合同 PBL 4 回 $\times 3$ 週（コアタイム 2 週+発表会）

$>2$ 年後期 -4 年前期「薬と疾病チュートリアル」

前期・後期 $\times 3$ 週（コアタイム 2 週+発表会）

- 2 年後期 : 感染症, アトピー性皮膚炎

・ 3 年前期 : 脳血管障害, パーキンソン病

- 3 年後期 : 狭心症, 心筋梗塞十心不全

- 4 年前期 : 気管支喘息, 悪性腫瘍

3 年後期「チーム医療による薬物治療」

4 学部合同 PBL 1 回 $\times 3$ 週（コアタイム 2 週+発表会）

4 年前期「チーム医療実践の基盤を構築する」

4 学部合同 PBL 1 回 $\times 2$ 日

模擬カルテなど実際の資料を用いた学部連携病棟実習の シミュレーション

(2) 統合型学習 (知識+技能十態度) 4-6 年

$>4$ 年後期「実務実習事前学習 : 病棟」

模擬カルテと SP・模擬医療スタッフを用いたファーマ シューティカルケア実習

5 日連続 : 患者情報収集 $\rightarrow$ 初回面談 $(R P) \rightarrow$ 問題点抽 出 (SOAP 作成) $\rightarrow$ 模擬医療スタッフとの討 議 $(\mathrm{RP}) \rightarrow$ 服薬指導 $(\mathrm{RP})$

$\mathrm{RP} ：$ ロルプレイ

5 年「病院・薬局実務実習」

病棟実習（担当患者，3 者ミーティングの実施）

4 週間 $\times 2$ 病棟

4 学部連携病棟実習（担当患者, 4 学部学生ミーティン グの実施） 1 週間

5 年「総合薬学演習」（選択）

実務実習のない期間 2 回 $\times 3-4$ 週

複雑な背景や病態を持つ患者シナリオの PBL

$>6$ 年「臨床判断と薬剂師」（選択）

薬局空口での臨床判断（グループ討議，RP） 9 日

急性疾患, 緊急時の臨床判断 (グループ討議, 臨床技能 実習）13日

技能（後半）を演習と実習を繰り返して学習するス ケジュールとした.

プライマリケアのための臨床判断としては，(1)基 本的症候（頭痛，腹痛）を訴える患者の疾患を推測 するため，適切な患者面談に基づくアルゴリズムの 作成，(2)責任ある適切な判断（トリアージ：救急対 応，受診勧奨，OTC での対応，生活指導などから の選択）を，小グループ討論による演習とロールプ レイを組み合わせて学習した（Fig. 3)。急性期医 療に参加するための臨床技能としては，(1)フィジカ ルアセスメント（脈拍・血圧測定，聴診), 心電図 

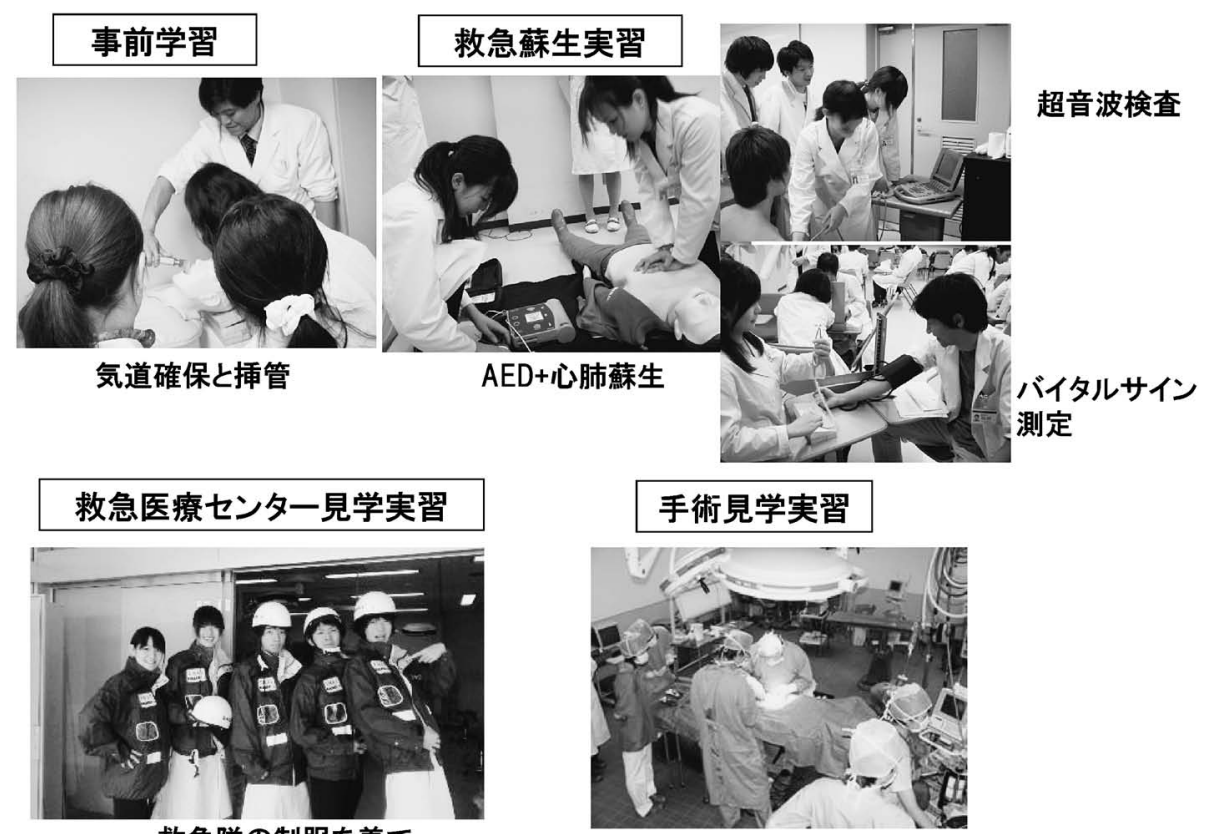

Fig. 2 Scenery in a Unit "Practice of Pharmacist and Medical Care for Emergency and Surgery"

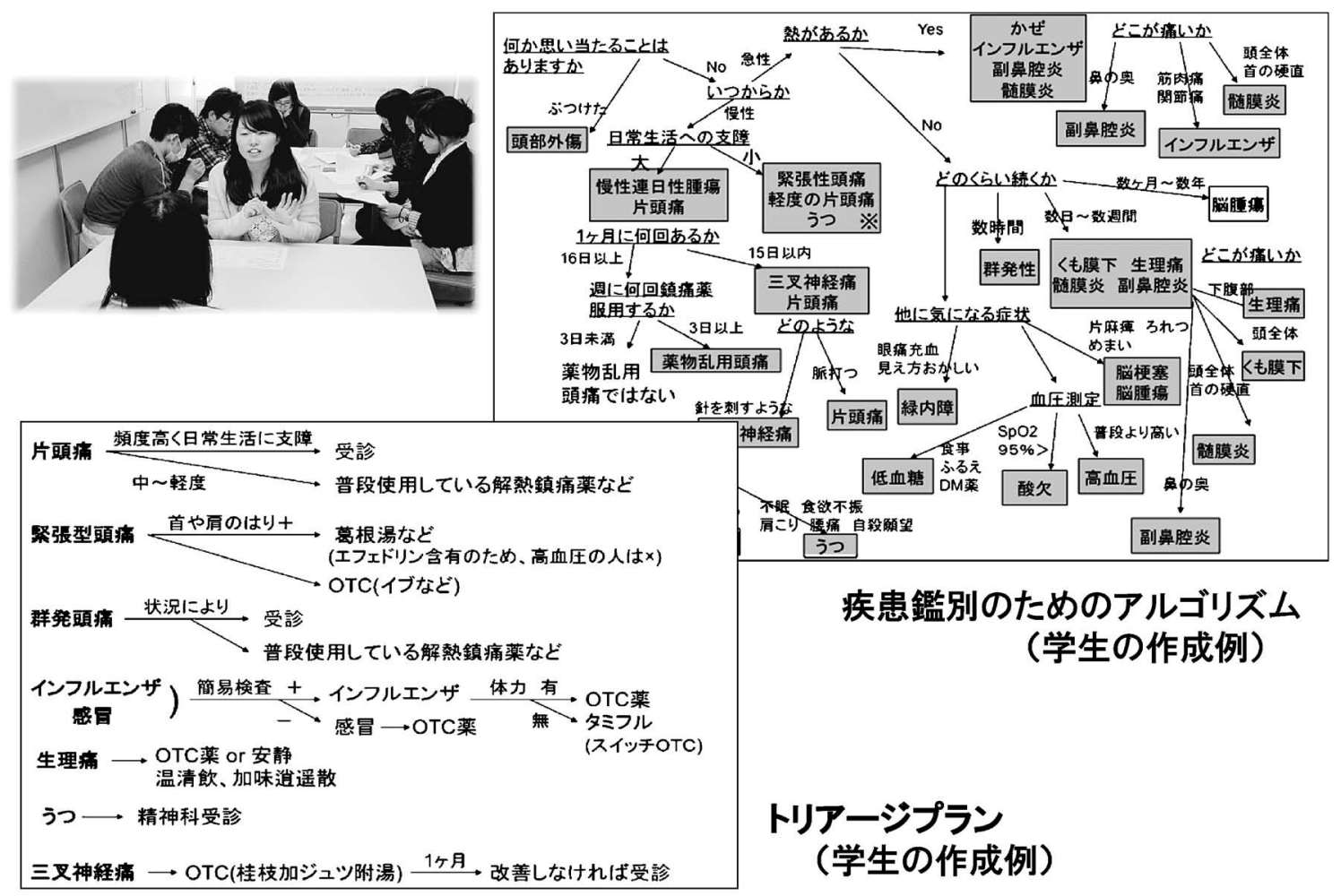

Fig. 3. Scenery of Clinical Assessment in a Unit "Clinical Judgment of Pharmacist"

などによる状態の把握，(2)注射・点滴の判断と実習 (シミュレーター), (3)救急処置（心臟マッサージと AED)，を小グループ討論による演習と実習（Fig. 4）を組み合わせて学習し，新たな技能の習得を評 価するため，OSCE（objective structured clinical ex- amination）形式の実技試験を 2 回実施した.

4.「地域への貢献」の体系的カリキュラム

コンピテンシー「地域への貢献」の説明文を以下 に示す.

・ 地域社会におけるプライマリケアの担い手と 


\section{身体所見の収集}

疾患シミュレーター人形(フイジコ)

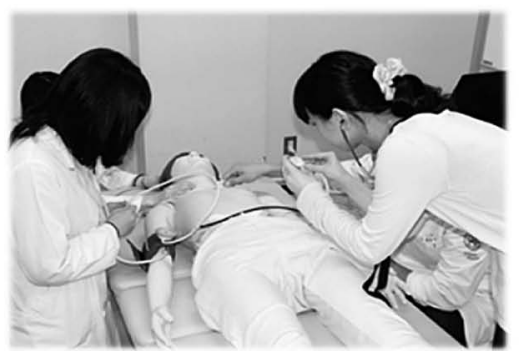

急変時の対応

1 次救命処置

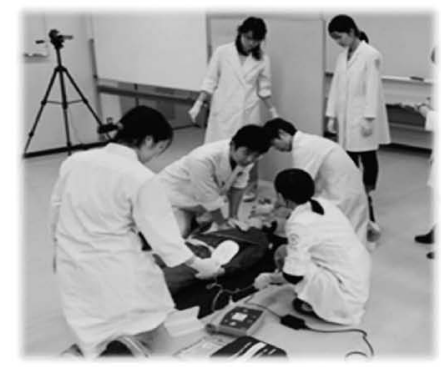

静脈路確保と採血手技

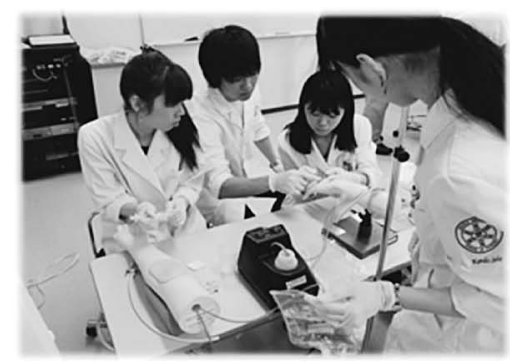

2次救命処置

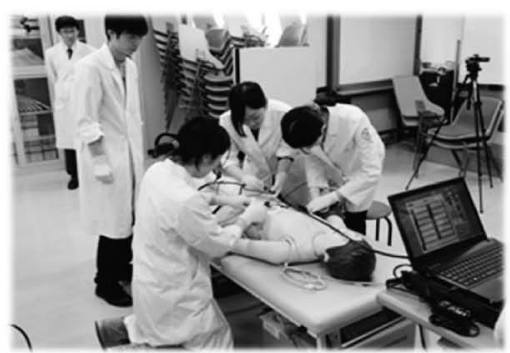

Fig. 4. Scenery of New Clinical Skill in a Unit "Clinical Judgment of Pharmacist",

して, セルフメディケーションの支援, 在宅医 療などの地域の医療・福祉との連携, 保健衛生 に係わる活動を通して，地域住民の健康回復・ 維持・向上に貢献する.

・ 街の科学者として地域の公衆衛生に貢献する.

卒業時に, このレベルに到達するため,「薬物治 療の実践と評価」と同様に，らせん型カリキュラム による体系的な学習の構築を進めている. その代表 的な科目を紹介する.

4-1. 地域における福祉の体験学習 : 福祉の現状 を知る 1 年次の早期体験実習では, 4 学部合同 の学生グループで, 福祉施設での 3 日間にわたる介 護支援を行うが (後述), さらに 3 年次には, 地域 における医療・福祉の実際のプロセスと医療チーム と薬剤師の役割を学習するため,「福祉の現状を知 る」を薬学部の選択科目（約 100 名）として実施し ている. 介護基礎実習，高齢者服薬ケア実習，高齢 者福祉施設実習（特別養護老人ホーム，介護老人保 健施設, グループホームなど 15 施設), 福祉関連業 務に係わる保険薬局見学（26 施設）を全員がロー テーションし, 最後にグループ討議と発表会を行う (Fig. 5).

4-2. 在宅医療の参加型学習 : 学部連携地域医療
実習「地域への貢献」と「チーム医療」の 2 つ のコンピテンシーに係わる学習として，6年次に 「学部連携地域医療実習」（選択科目, 平成 24 年度 は約 20 名）を実施している．在宅医療を中心に, 診療所, 歯科診療所, 薬局, 訪問看護ステーション などの連携のとれた地域医療を 2 週間, 学習する. 在宅患者を 3-4 名の学部合同グループが担当し, 在 宅医療に係わる様々な専門職の役割を相互に理解す るとともに, 最善の医療・介護を医療チームとして 討議し提案することを目的とした実習である.

平成 23 年度は東京都内 2 地域と山梨県富士吉田 市 1 地域で実施した（平成 24 年度は 6 地域）。それ ぞれに9-11 の医療・福祉施設が加わり，各施設の 見学と在宅医療への参加を組み合わせた実習であ り，各学部生のスケジュールを事前に作成したた め, 円滑に実習を実施することができた。難治神経 疾患の患者を担当し, 数回, 担当患者宅を訪問した が，それ以外にも医療スタッフと 10-20名の在宅患 者宅への訪問に同行した（Fig. 6)。ほぼ毎日，学 生グループは診療所の医師を交えてミーティングを 行い, 担当患者の病態, 治療やケアについて討議 し，最終日には，実習のまとめを発表した。 


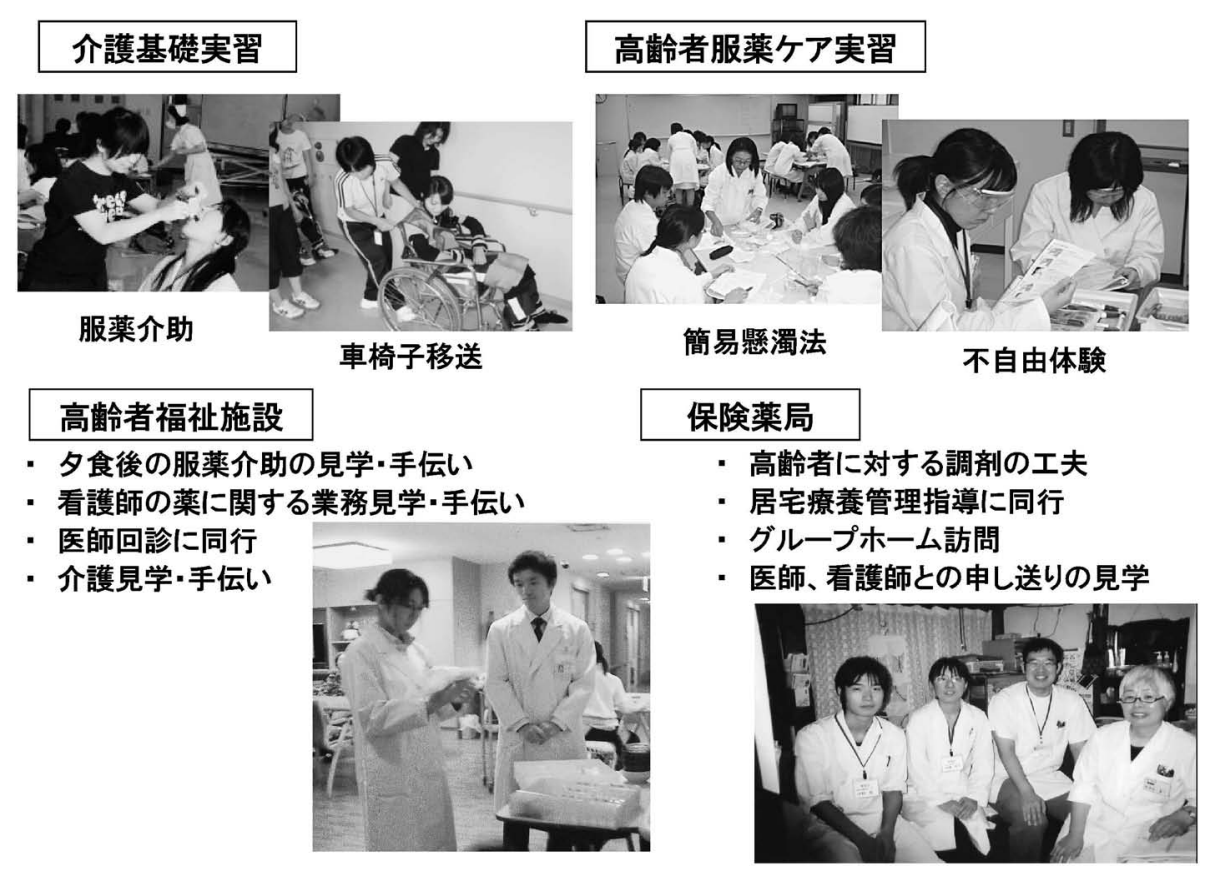

Fig. 5 Scenery in a Unit "Present State of Walfere Service for Elderly"

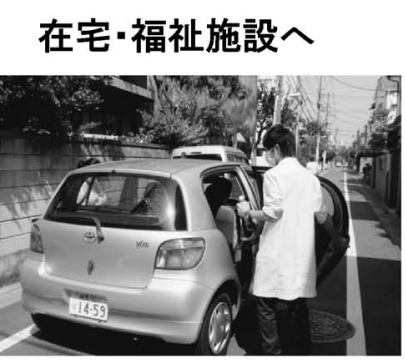

薬剂師に同行

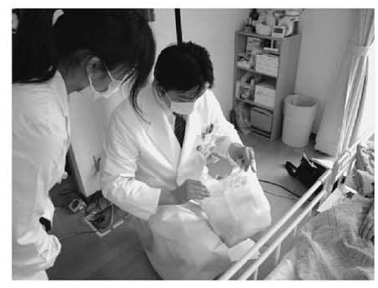

患者宅への訪問
医師とのミーティング

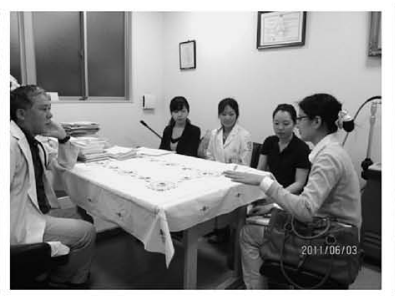

歯科医師に同行

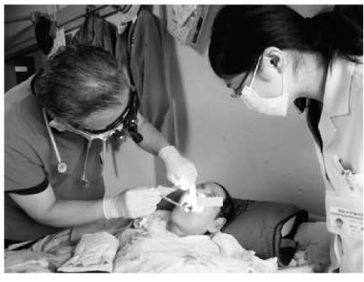

在宅歯科診療
医師に同行

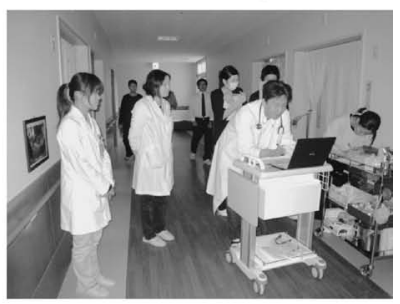

施設での診療

看護師に同行

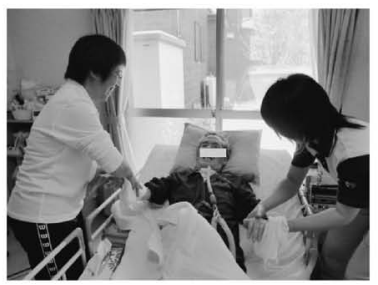

患者宅でのケア

Fig. 6. Scenery in a Unit "Interprofessional Practicum of Community Medicine"

5.「患者中心のチーム医療」の体系的カリキュ ラム

昭和大学の教育理念「学部の枠を越えてともに学 び，互いに理解し合え，協力できる人材を育成す る」を具現化するため,「患者中心のチーム医療」 に関しては，全学を挙げた体系的，段階的な多職種 連携教育（interprofessional education; IPE）カリ キュラム構築に取り組んでいる. ${ }^{2)}$ その到達レベル
を明記したコンピテンシーの説明文を以下に示す．

-ともに医療を担う多職種の職能を相互に理 解, 尊重して, 患者に係わる情報を共有できる.

・ 多職種と連携・協力しながら薬剤師の専門性 を発揮し，患者中心の医療を実践できる.

昭和大学では, 平成 18 年度から, 文部科学省の 「地域医療等社会的ニーズに対応した質の高い医療 人養成推進プログラム」（医療人 GP，平成 18-20 
年度）及び「大学教育推進プログラム」（平成 2123 年度）の支援を受け，全学部，全学年にわたる 学部連携教育カリキュラムを構築した。 6 年間にわ たつて，段階的に学習の場と内容を広げ，確実に チーム医療に必要な能力を修得する学習となるよう に工夫している，すなわち，低学年では，チーム医 療の基盤作りとして，大学内外での各種の体験実習 やPBL チュートリアルなどの問題解決型学習，高 学年では, 大学内外の医療施設や地域社会での実践 的なチーム医療学習を，いずれも原則的に 4 学部合 同カリキュラムとして実施している（Fig. 7)。以 下に代表的なチーム医療学習について概説する。

5-1. 学部合同早期体験実習 1 年次の全寮制 の環境を活かした実習として，3 週間にわたる体験 実習を行っている. 4 学部合同の学生グループで, (1)病院見学 (1 日, 病院の各部署の見学), (2)福祉 施設体験（3 日，施設利用者に対するサポートの体 験), (3)AED+心肺蘇生（半日）及び外科的救急処 置（半日）の実習を行い（Fig. 8), さらに，薬学 部独自の体験実習として薬局見学, 医薬品・医療器 具製造工場見学，植物介在療法実習を加えて，最終 日に討議・発表を行う。 4 学部で約 600 人の 1 年生 が必修で実施するため, 平成 23 年度は山梨県内外 の薬局 19 力所, 医薬品. 医療器具製造工場 4 力
所，病院 10 力所，福祉施設等 39 力所という全国の 医療系学部の中でも最大の規模・内容となったが, チーム医療の実際を見聞し，その重要性を学ぶとと もに，学習に対するモチベーション付けに有用な実 習となっている.

5-2. 医療・福祉におけるチーム医療のプロセス の見学学習 $2 \cdot 3$ 年次では, 各学部がそれぞ れ, 学内外の医療・福祉の現場で, 多職種が協力し た医療・福祉のプロセスと連携の実際を，見学を通 して学習する. 薬学部の 2 年次「診療の流れを知る」 では，大学病院病棟での看護見学 (1 日， 50 病棟), 病院・診療所の医師の外来診療見学 $(1$ 日，29施 設), 病院薬剂師業務（薬剂部十病棟）見学（1日） を全員がローテーションで学習する（Fig. 9).

さらに, 前述した 3 年次の「福祉の現状を知る」, 「救急医療・外科医療と薬剤師」での学習も通して, 現状では薬剤師があまり関与していない急性期医療 から地域での慢性期医療・福祉まで，各職種の職能 とその連携の実際を身近で学ぶことができる.

5-3. PBL チュートリアルによる問題解決型学習 近年, 多くの医療系大学で積極的に PBL チュー トリアルが取り入れられているが，昭和大学では， チーム医療学習を目的に 4 学部連携型の PBL チ ユートリアルを $1 \cdot 3 \cdot 4$ 年次（保健医療学部は 1 ・

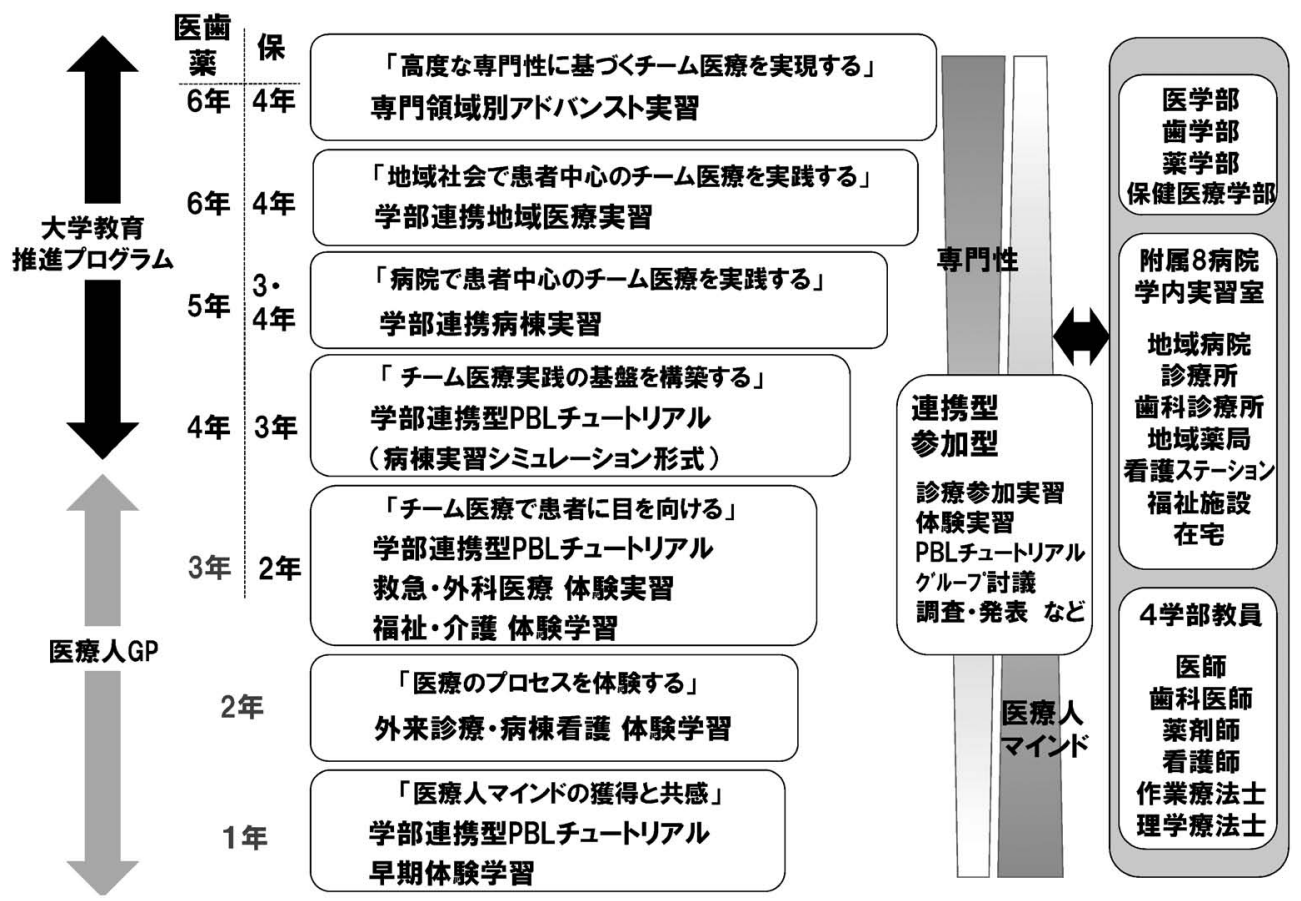

Fig. 7. Systematic and Gradual Interprofessional Education Curriculum for the Team Medical Education in Showa University 


\section{福祉施設体験 3日間}

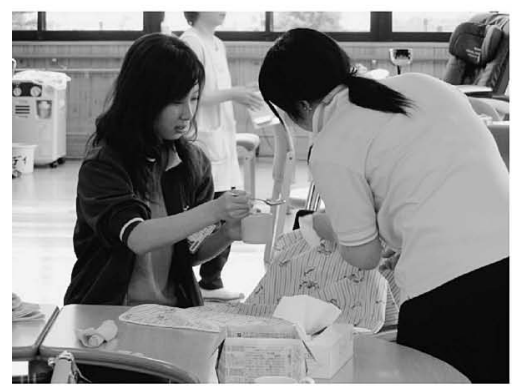

$A E D+心$ 肺蘇生 半日

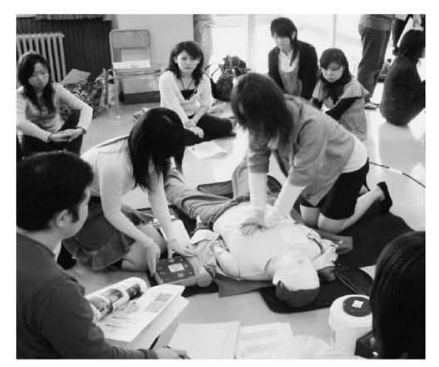

病院見学 1日

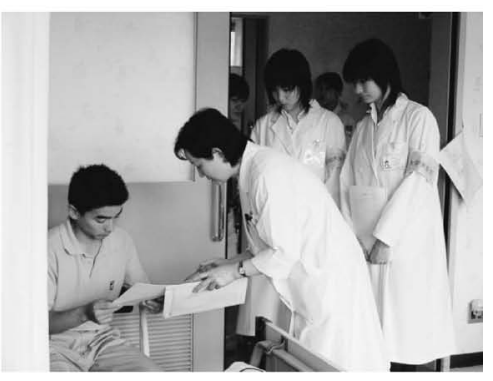

\section{外科的救急処置 半日}

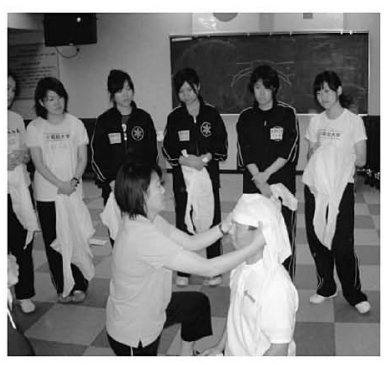

Fig. 8. Scenery in a Unit "Early Exposure"

\section{看護見学実習}

-病棟の看護業務の見学と手伝い(2人1組)

-病棟でのチ一ム医療の見学·体験

·患者·医療スタッフとの適切な態度

\section{外来見学実習}

- 外来診療の一連の流れを見学(2人1組) -チーム医療の連携の見学 - 患者の症状や心理状態の実際 - 医師の処方や面談の実際
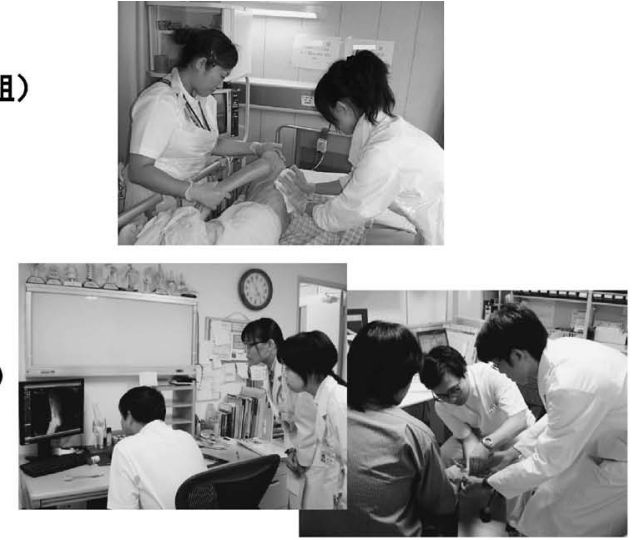

\begin{tabular}{|l|}
\hline 薬剂師業務見学 \\
\hline ·薬局業務 \\
調剂の流れ \\
·病棟業務
\end{tabular}
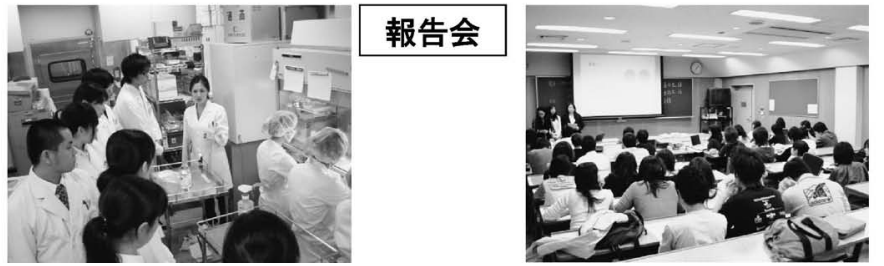

Fig. 9. Scenery in a Unit "Process of Clinical Medicine"

$2 \cdot 3$ 年次）に実施し，その内容も学年に従い，徐 々に臨床の場面設定に近づける累進型としている.

1 年次には, 福祉・介護, 終末期医療, 寮生活, 栄養・健康に関する話題など, 身近な話題を基にし たシナリオで, 富士吉田キャンパスで 1 年間に 3 週 $\times 4$ 回（コアタイム 2 回＋発表会）の PBL チュー トリアルを実施している（Fig. 10). 3 年次には,
ある程度複雑で全学部学生が関心を持つ臨床症例を 基にしたシナリオやビデオを用意し，旗の台と横浜 キャンパスで 3 週 $\times 1$ 回，実施している. 3 年生に なると，それぞれの職種の視点で患者症例を解析 し，他学部の学生にもわかり易く説明し，全員で患 者の多様な問題点を抽出して治療やケアの全般につ いて提案を行う積極的な取り組みが認められる。 4 
コアタイム1 第1週

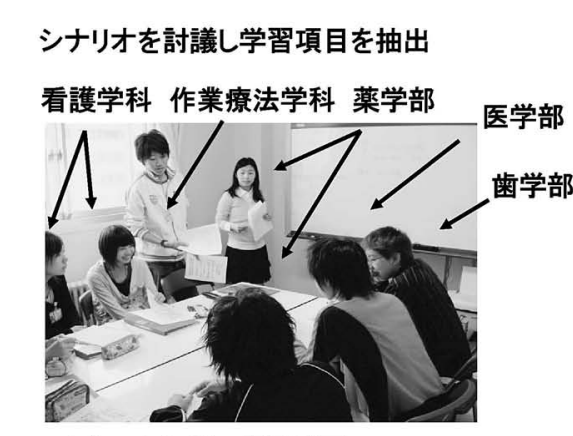

コアタイム2 第2週

各自の学習内容を提示し、合意を作成

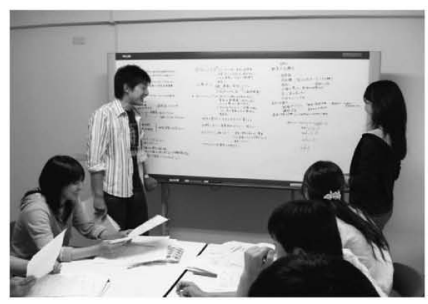

自学自習 第1週 第2週

学習項目に対し各自が自習し、学習内容のサマリーを

PBL支援|Tシステムを利用し、ファシリリテータに提出

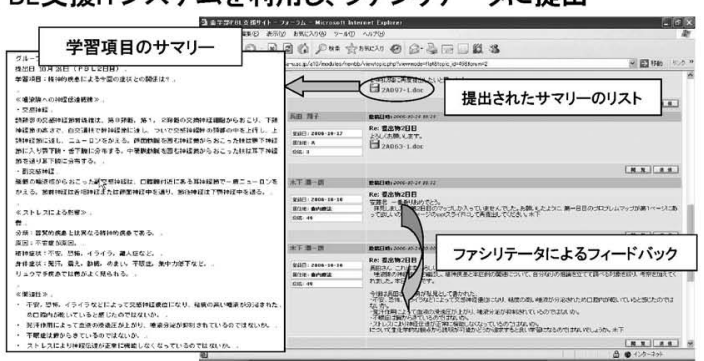

グループ発表 第3週

学生の発表·質疑にリリースパーソンが簡潔な解説

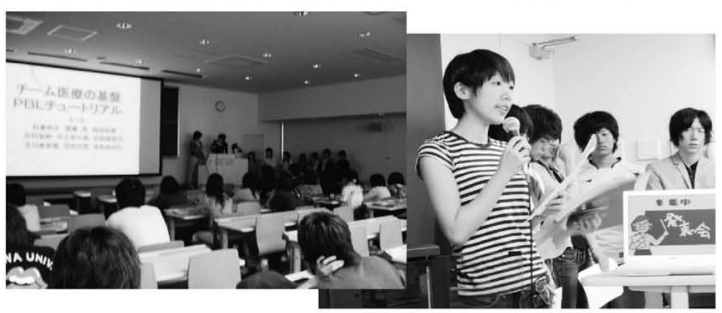

Fig. 10. Scenery in "Interdisciplinary (Interprofessional) PBL Tutorial" in Fujiyoshida Campus

年次でも 3 週 $\times 1$ 回，実施するが，学部連携病棟実 習の事前学習として位置づけ，診療録，看護記録な ぞの病棟で用いられている書式で入院患者を提示 し，入院後の問題を自らが診療録などから抽出する ことから取り組み，小グループ討議でチーム医療に よる最善の治療やケアをまとめる.

昭和大学の 1 学年の 4 学部生, 約 600 人を $60-70$ の学部混合のグループに分けて, 学部連携型 PBL チュートリアルを実施するには, 学習環境の整備 （PBL ルームや IT 支援システムなど） とともに， 全学部学生が関心を持つシナリオの作成と, 標準的 な指導を行うための教員（ファシリテーター）の養 成が必要である。こうした準備と円滑な運営にかな りの手間を要するが，チーム医療の有用性を学生自 身が実感することができる実り多い学習となってい る.

\section{5-4. 学部連携病棟実習昭和大学では医学} 部, 薬学部の 5 年生は全員が附属病院で長期実習を 実施している。この実習期間を利用して，平成 23 年度から, 医・歯・薬学部 5 年生, 保健医療学部看 護学科・作業療法学科 4 年生, 理学療法学科 3 年生 の学部合同チーム（4-6 人程度, 約 120 チーム) に よる 1 週間の学部連携病棟実習を必修で実施してい る。実施病棟は附属 7 病院の約 40 病棟で, 120
チームの実習を行うために $6 \cdot 10 \cdot 11$ 月の 3 期に分 けて実施する。実習では，同じ患者を学部合同チー ムが連携，協力しながら担当し，毎朝夕にミーティ ングをして, 患者情報の共有と治療・ケアについて 討議, 提案するとともに, 他学部の学生の活動を見 学することで相互理解を深める実習である（Fig. 11)。実習の指導（ミーティングや最終日の発表会 のファシリテート) や評価のために，4学部から指 導担当教員を病棟毎に派遣し, 多職種の病棟スタッ フとともに協力しながら学生の支援を行っている.

円滑な実習の実施のために，事前に各病棟のス夕 ッフ (医師, 歯科医師, 薬剤師, 看護師, リハビリ 技師）や指導担当教員を集め, ワークショップ形式 で学部生毎の詳細なスケジュール作成と指導方法の 説明を行つた。

医学部生は診断や外科治療, 薬学生は薬物治療, 歯学部生は口腔ヶア, 看護学生は患者心理・介護・ quality of life (QOL), 理学・作業療法学生はリハ ビリテーションや activities of daily living (ADL) の視点から, 患者の多くの情報を収集・検討し， そ れぞれの学部実習では気付くことのない幅広い視点 から討議を行い，入院中から退院後までにわたる多 彩な治療やケアを提案した。 また, 他学部の学生の 実習や業務を見学することで，相互の職能に対する 


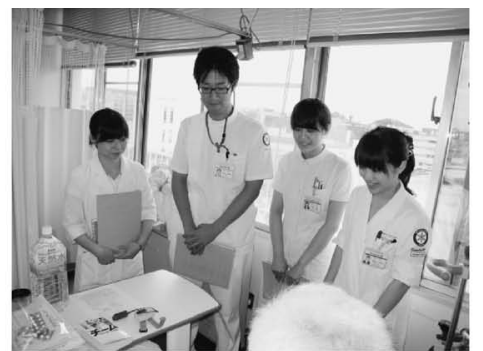

担当患者への挨拶からスタート

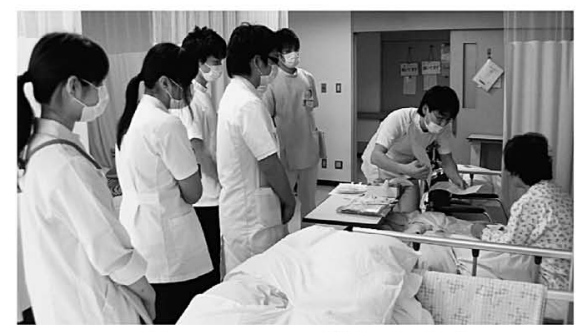

回診に同行し、情報を共有

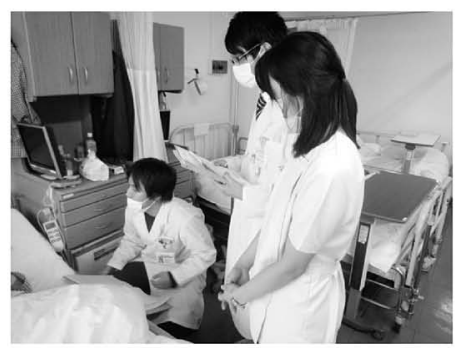

薬学部学生の服薬説明の見学

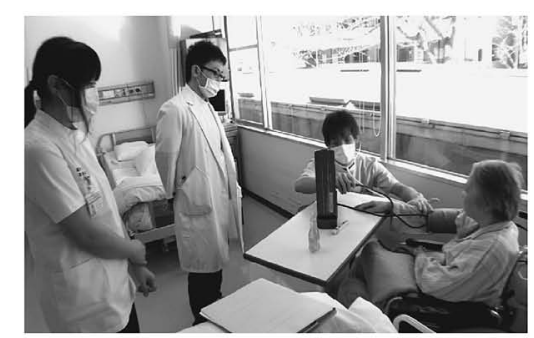

看護学生のバイタルサイン測定やケアの見学

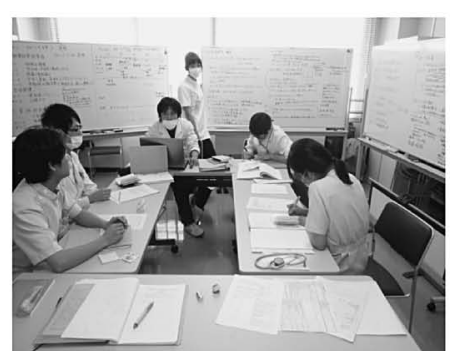

朝タの学生ミーティング

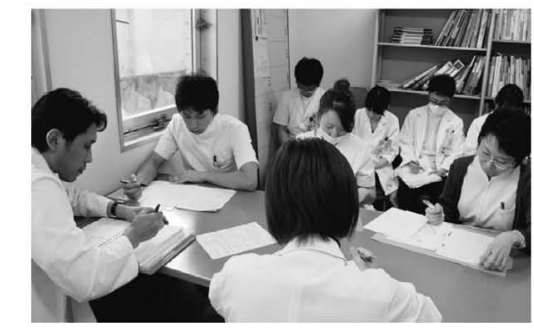

カンファランスに参加して治療·ケアを提案

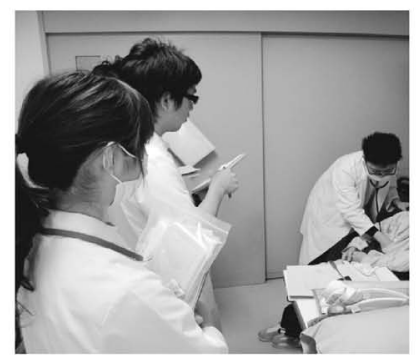

医学部生の診察の見学

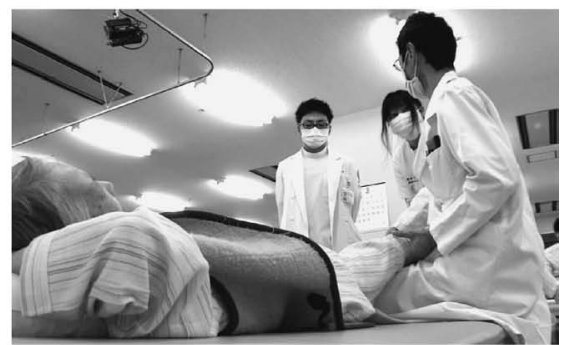

リハビリテーションの見学

Fig. 11. Scenery in "Interdisciplinary (Interprofessional) Hospital Practicum”

理解が深まり，アンケート結果から，多くの学生が 「患者の問題を把握し, 解決するためには, チーム 医療が重要であることがわかつた」という感想を持 つたことがわかった。

5-5. 学部連携アドバンスト病院実習と学部連携 地域医療実習選択実習 (平成 24 年度は約 30 名) として, 最終学年の医・歯・薬学部 6 年生, 保健医 療学部 4 年生を対象に, 学部連携アドバンスト病院 実習と前述の学部連携地域医療実習を 2 週間ないし 4 週間（前期）実施している.
学部連携アドバンスト病院実習は学生が希望する 専門領域（がん化学療法, 乳がん治療, 感染制御, 周産期医療, 糖尿病, 救急医療など）で，大学附属 病院の高度先進医療におけるチーム医療を，実践を 通してより深く学習することを目的としたものであ り，それぞれの専門領域の病棟あるいは外来診療 に，学部合同グループとして参加する実習である.

平成 23 年度は, 以下の領域で実習を実施した。

- 4 週間コース

(1) 糖尿病：藤が丘病院 糖尿病代謝内分泌内科 
病棟

(2) 周産期医療：大学病院 NICU 及び小児科病 棟

- 2 週間コース

(1) 感染制御：大学病院 臨床感染症

(2) がん化学療法：大学病院 腫瘍内科

(3) 乳がん治療：大学病院 ブレストセンター

(4) 救急医療：大学病院 救急医療センター

本実習は, 最終学年の学生が自らの関心を持つ領 域での参加型学習であるため, 高い専門性を要する 高度なチーム医療の学習ではあるが，学生間のみな らず，指導するスタッフとも積極的に連携して十分 な学習成果が得られたようで, 学生の満足度も指導 スタッフの評価も高い実習となつている.

6. おわりに

以上のように，昭和大学では将来の医療において 期待される薬剤師業務を想定し, 医系総合大学の特 色を生かした新たな臨床能力を育成する学習力リキ ユラムを構築している. また，学習アウトカム（コ ンピテンシー）を設定し, 体系的, 段階的な学習と なるようにカリキュラム構成の工夫を行い, $\mathrm{PBL}$ チュートリアル, 統合学習, 学部連携実習, アドバ
ンスト実習，新しい臨床技能の実習など，様々な学 習方法を段階的に組み合せ，総合的な臨床能力の修 得を目指している.今後は，学習アウトカムの最終 到達度を確認するための評価（アドバンスト OSCE など）を取り入れることも検討したい.

\section{REFERENCES}

1) Tanabe M., Asahina M., Ito S., Maeda T., Noguchi H., Shirasawa H., Tagawa M., Medical Education (Japan), 42, 263-269 (2011).

2) Kiuchi Y., Nakamura A., Masuda Y., Takagi Y., Takamiya Y., Kataoka R., Mukai Y., Geshi E., J. Interprofessional Collaboration in Health and Social Care, 4, 32-39 (2012).

3) Notification of Health Policy Bureau, Ministry of Health, Labour and Welfare: 〈http://www. mhlw.go.jp/shingi/2010/05/dl/s0512-6h.pdf $\rangle$, cited 16 May, 2012.

4) Japanese Society of Hospital Pharmacists, Interpretation and Specific Example: 〈http:// www.jshp.or.jp/cont/10/1029-2.html $\rangle$, cited 16 May, 2012. 